\title{
Evaluation of Pigeonpea Genotypes for Growth and Yield Characters
}

\author{
D. Hanumanthappa ${ }^{1}$, S. N. Vasudevan ${ }^{2}$, N. M. Shakuntala ${ }^{3}$, \\ N. M. Muniswamy ${ }^{4}$, Sangeetha I. Maacha ${ }^{5}$ and Umesh Hiremath \\ ${ }^{1}$ Agricultural Research Station, Siruguppa, ${ }^{2}$ VC Farm Mandya, ${ }^{3}$ Department of SST, \\ ${ }^{4}$ Department of GPB AC Kalaburagi, ${ }^{5}$ Department of SST, UAS, Raichur, ${ }^{6}$ Seed Unit, UAS \\ Raichur, UAS, Raichur-584 104, Karnataka, India \\ *Corresponding author
}

\begin{tabular}{|l|}
\hline Key w or d s \\
$\begin{array}{l}\text { Seed, Pigeonpea, } \\
\text { Genotypes, Yield }\end{array}$ \\
\hline Article Info \\
\hline $\begin{array}{l}\text { Accepted: } \\
\text { 22 March } 2020 \\
\text { Available Online: } \\
10 \text { April } 2020\end{array}$ \\
\hline
\end{tabular}

\section{A B S T R A C T}

A field experiment was conducted during kharif, 2016 at the Main Agricultural Research Station, Raichur. The experiment was laid out in Lattice Design with three replications. In the present study, the nature and magnitude of genetic diversity, growth and yield characters were assessed among 64 pigeonpea genotypes. Among the 64 genotypes GRG-2009 registered significantly highest leaf area $\left(15.80 \mathrm{dm}^{2}\right.$ plant $\left.^{-1}\right)$, number of branches plant ${ }^{-1}$ (57.01), chlorophyll content (66.82 SPAD), pod weight $(9.06 \mathrm{~g})$, pod length $(6.13 \mathrm{~cm})$, seed yield $\left(54.16 \mathrm{~g} \mathrm{plant}^{-1}\right.$ and $1687.21 \mathrm{~kg}$ ha $^{-1}$ ). Whereas, ICP-14944 (71.72 days) and ICP-14944 (133.17 days) took less number of days to 50 per cent flowering and days to maturity compared to other genotypes. Among 64 genotypes GRG-2009 and ICP11320 are best performers for plant growth and yield attributing characters.

\section{Introduction}

Pigeonpea [Cajanus cajan (L.) Millsp] is an important grain legume that has primarily originated in the Indian sub-continent. It is now grown in many parts of the world including southern Africa particularly the region encompassing Kenya, Mozambique, Malawi and Southern Tanzania (Hoghjensen et al., 2007). This region is considered as a secondary centre of diversity for pigeonpea. It is an often-cross pollinated crop (20-70\%) with diploid $(2 \mathrm{n}=2 \mathrm{x})$ chromosome number of 22 with genome size of 833.1 Mega base pairs (Varshney et al., 2012).

India is considered as the native of pigeonpea because of its natural genetic variability available in the local germplasm and the presence of its wild relatives in the country. 
The genus Cajanus comprises of 32 species and India embraces 18 species (Van Der and Maesen, 1980). There was a major dispute among historians on the origin of pigeonpea. De (1974) believes that Cajanus species, together with the closely related Atylosia were first established in northern and on the Deccan plateau 3,500 years ago. Among these claims, historians agree that the true origin of pigeonpea could be India in general and Eastern ghats in particular.

Pigeonpea has an extensive root system that enables it to tolerate drought and improve soil structure by breaking hard pans and make it a successful crop in areas of low and uncertain rainfall. It has a wide range of maturity which helps in its adaption in a wide range of environments and cropping systems. It is a major source of protein for several resource poor rural and urban families of Asia, Africa. Being a pulse crop, pigeonpea enriches soil through symbiotic nitrogen fixation, releases soil-bound phosphorous, recycles the soil nutrients, adds organic matter and other nutrients that make pigeonpea an ideal crop for sustainable agriculture (Saxena, 2008). Besides, it is mainly used as dry dehulled splits, its tender green seeds and pods are used as vegetable. Its dry crushed seeds have high protein content (20-25\%) which act as major source of protein for vegetarian people.

More than 85 per cent of the world's pigeonpea is produced and consumed in India. It is commonly known as redgram or arhar or tur or thogari. The world acreage of pigeonpea is $4.86 \mathrm{~m}$ ha with an annual production of $4.1 \mathrm{mt}$ and productivity of 900 $\mathrm{kg} / \mathrm{ha}$ across 50 countries (http://www. faostat.fao.org). India is the largest producer and consumer of pigeonpea with an annual production of $3.29 \mathrm{mt}$ in an area of $3.88 \mathrm{~m}$ ha with a productivity of $849 \mathrm{~kg}$ per ha, followed by Myanmar $(0.60 \mathrm{mt})$, Malawi $(0.16 \mathrm{mt})$ and Kenya $(0.10 \mathrm{mt})$. In India, it is one of the very important grain legumes and mainly grown in the states of Maharashtra, Karnataka, Madhya Pradesh, Uttar Pradesh and Gujarat. In Karnataka it is grown in an area of about 0.82 $\mathrm{m}$ ha with a production of $0.60 \mathrm{mt}$. Average productivity of pigeonpea in Karnataka accounts for $700 \mathrm{~kg}$ per ha and its potential yield marked up to 3.5 tonnes per ha. Its area, production and productivity in India in last five decades showed that there was about two per cent area increase per year but the yield levels were stagnated around 600-700 kg per ha (Anon., 2014).

The presence of genetic variability and genetic diversity in any crop species is an important tool for a breeder to plan his breeding objectives with relevant breeding strategies. Phenotypic evaluation of germplasm is the initial step for variety development.

So, phenotypic and genetic diversity assessment and estimation of relationship among cultivars are very helpful for germplasm improvement. In the present investigation, a total of 64 pigeonpea genotypes were evaluated for growth and yield characters.

\section{Materials and Methods}

A field experiment was conducted during kharif, 2016 at the Main Agricultural Research Station, Raichur. Raichur is situated on $16^{\circ} 12^{\prime}$ North latitude, $77^{\circ} 20^{\prime}$ East longitude and at an elevation of 389 meters above mean sea level and is located in North Eastern Dry Zone of Karnataka. The soil of the experimental site was medium black with sandy loam texture. The experimental material for the present study consisted of 64 pigeonpea genotypes which were obtained from Agricultural Research Station, Kalaburagi. The experiment was laid out in Lattice Design with three replications. Each 
genotype was sown in 6 rows of 3 meter length with a spacing of $90 \mathrm{~cm}$ and $30 \mathrm{~cm}$ between the rows and plants respectively.

\section{Growth parameters}

\section{Plant height (cm)}

Plant height from ground level up to the growing tip of the plant was recorded from five tagged plants and the mean plant height was worked out and expressed in centimeters.

\section{Number of branches plant ${ }^{-1}$}

The number of branches on main stem was counted and the average was expressed as number of branches per plant.

\section{Leaf area per plant $\left(\mathrm{cm}^{2}\right.$ plant $\left.^{-1}\right)$}

The leaf area per plant was worked out by disc method on dry weight basis as per the procedure suggested by Vivekanandan et al., (1972).

$$
\mathrm{LA}=\frac{\mathrm{Wa} \times \mathrm{A}}{\mathrm{Wd}}
$$

Where,

$$
\mathrm{LA}=\text { Leaf area }\left(\mathrm{dm}^{2}\right)
$$

$\mathrm{Wa}=$ Oven dry weight of all leaves (inclusive of 10 disc weight)

$\mathrm{Wd}=$ Oven dry weight of 10 discs $A=$ Area of the $10 \operatorname{discs}\left(\mathrm{dm}^{2}\right)$

\section{Dry matter production per plant (g plant $\left.{ }^{-1}\right)$}

Plant samples for dry matter studies were collected at harvest. At each sampling, five plants were uprooted at random in each treatment and partitioned into leaf, stem and reproductive parts. These samples were oven dried at $70^{\circ} \mathrm{C}$ in hot air oven for 72 hours till a constant weight was obtained. The dry weight of different plant parts was recorded. The total dry matter production per plant was obtained with the summation of dry weight of all plant parts and was expressed on per plant basis $\left(\mathrm{g}\right.$ plant $\left.{ }^{-1}\right)$.

\section{Chlorophyll content of pigeonpea leaves (SPAD value)}

The chlorophyll content of green leaves of each of five tagged plants was recorded at 45 and 90 DAS. For this estimation, chlorophyll meter (Model, SPAD-502) was used and values were obtained.

\section{Days to 50 per cent flowering}

The number of days from sowing to the opening of flowers in fifty per cent of plants in each genotype was recorded separately for two replications and then average was taken.

\section{Yield parameters}

\section{Days to maturity}

Number of days from sowing to physiological maturity of the plant was observed and recorded in number of days.

\section{Pod weight (g)}

Pod weight of 15 pods of each genotype was weighed using balance and mean was computed.

\section{Pod length (cm)}

Pod length of 5 pod of each genotype was measured using scale and mean was computed.

\section{Test weight (g)}

Seed samples from the produce of each plot were taken and 100 seeds from these samples were counted and weighed. 


\section{Seed yield (g plant $\left.{ }^{-1}\right)$}

The average weight of seed yield from five randomly selected plants from each genotype was recorded as seed yield per plant after drying the seeds to the moisture level of 9-10 per cent.

\section{Seed yield $\left(\mathrm{kg} \mathrm{ha}^{-1}\right)$}

The total plants in the plot were harvested and threshed. The average plot yield was recorded and converted into the hectare yield expressed in kilogram per hectare.

\section{Results and Discussion}

Any crop improvement programme depends on the utilization of germplasm stock available in different research organizations / institutes of the world. Pigeonpea yield is a quantitative polygenic character and highly influenced by environment. Extent and significance of association of yield with yield components should be considered, while determining the selection criteria of germplasm on the basis of available genetic variation (Grafius, 1956). The success of breeding programme also depends upon the amount of genetic variability present in the population and extent to which the desirable traits are heritable. Different morphological traits play an important role for more pigeonpea production with new plant type characteristics associated with the plant yield.

\section{Growth parameters}

Among the genotypes studied, significantly highest plant height was recorded in GPHR08-11 $(183.83 \mathrm{~cm})$. Whereas, lowest plant height was registered in ICPL 14001 (128.13 $\mathrm{cm})$ at harvest (Table 1). The mean performance of plant height ranged from $128.13 \mathrm{~cm}$ to $183.83 \mathrm{~cm}$ with an average mean of $153.17 \mathrm{~cm}$, which indicated the presence of large variation for this trait. Such variation among the genotypes could be due to genetic makeup of varieties (Hussain et al., 2011 and Sohrabi et al., 2012). High genetic advance in genotypes indicate the major role of additive component of genetic variance where selection may be effective for development of varieties. The differential growth with respect to plant height observed among the genotypes might be attributed to differences in genetic characteristics of the individual entries, including rapid growth rates, tallness or shortness of species (Enujeke, 2013).

Branching ability in pigeonpea is an important trait for seed production. Number of branches plays a major role in determining pigeonpea yield since it is closely related to number of pods per branches in single plant. In the present study, wide range was observed for number of branches plant ${ }^{-1}$ (39.16 to 57.01 ) with a mean of 46.59. Significantly highest number of branches plant $^{-1}$ has recorded in GRG-2009 (57.01). Whereas, PRIL-B-165 genotype recorded lowest number of branches plant ${ }^{-1}$ (39.16) at harvest (Table 1). High heritability coupled with high genetic advance was suggestive of influence of additive gene action. The results of the present study are in agreement with Vange and Egbe (2009) and Saroj et al., (2013). The differential response of branches in the genotype could be attributed to its genetic potentiality of the genotypes which is primarily influenced by heredity.

Leaf area is the efficiency of photosynthetic process, contributing greatly to yield. High leaf area as reported by Effisue et al., (2009) indicated that leaf area is good selection criterion for increasing yield. Thus, genotype with high leaf area could be higher yielding compared to low leaf area genotypes. Results of the present investigation, revealed 
significant difference due to genotypes for leaf area. Among the genotypes, GRG-2009 recorded highest leaf area $\left(15.80 \mathrm{dm}^{2}\right.$ plant $\left.^{-1}\right)$ and lowest was noticed in PRIL-B-165 (13.01 $\mathrm{dm}^{2}$ plant $\left.{ }^{-1}\right)$ at harvest. The mean performance of leaf area plant ${ }^{-1}$ ranged from 13.01 to $15.80 \mathrm{dm}^{2}$ plant $^{-1}$ with mean value of $14.33 \mathrm{dm}^{2}$ plant $^{-1}$ (Table 1). Leaf area increased with crop growth period and reached at its maximum value at full flowering stage in each variety. Afterwards, it started declining as crop moved towards maturity as a result of senescence in old leaves. Higher leaf area at harvest is useful in maintaining the current photosynthesis, so that it helps in pod filling and development. The differences observed in leaf area among the genotypes could be attributed to the differences in leaf arrangement, photosynthetic activities of leaves, differences in chlorophyll content and activity of photosynthetic enzymes (Enujeke., 2013).

Chlorophyll content indicates photosynthetic efficiency of leaves. The variation in chlorophyll content among the studied varieties was assessed at different stages. The chlorophyll content varied from 42.20 to 66.82 with mean value of 55.28 at 90 DAS. GRG-2009 had the highest (66.82) chlorophyll content and the lowest (42.20) was recorded in PRIL-B-165 (Table 1). Chlorophyll content increased up to flowering and decreased gradually towards harvest, which might be due to senescence of leaves at the time of harvest. Chlorophyll content plays a vital role on pod filling and most important element of photosynthesis. Munshi (2005) reported that seed yield is positively correlated with chlorophyll content. In the present investigation high yielding pigeonpea genotypes also showed higher chlorophyll content. These results are closely in agreement with earlier reports of Ashrafuzzaman et al., (2009) and Begum et al., (2015).
Dry matter production is an important yield contributing character and the basic vegetative phase is essential for the development of reproductive organs. Although, the dry matter production in general is the indicative of the efficiency of the genotypes, the pattern in which it is distributed in different plant parts would give a better understanding of the genotype. Accumulation of dry matter in different plant parts such as leaf, stem and pod was significantly higher in case of GRG-2009 (264.04 g) which was on par with ICP-11320 (261.31 g) at harvest (Table 1). This could be due to the increased photosynthetic activity as this genotype possessed high leaf area. This may also be attributed to improvement in growth attributing characters like plant height, number of leaves, leaf area and leaf area index. These results are in accordance with Jagathjyothi et al., (2012).

Flowering and maturity duration are an important characteristics which are frequently considered before release of a variety for commercial cultivation. Early flowering and maturity duration ensures the visible uniformity of a crop field which is always preferred by farmers. Development of early maturing genotypes is not only important for pigeonpea crop improvement but also for climate mitigation as drought escape mechanism for areas with marginal rainfall pattern. Variation among genotypes for days to flowering, particularly the medium and late flowering genotypes could be effective selection criteria for areas with bimodal rainfall like India. Late flowering could be advantageous if genotypes flower near the end of rainy season when moisture is sufficient. In the present investigation wide variation was observed for days to 50 per cent flowering and maturity among the studied genotypes. ICP-14944 showed best uniformity of flowering and maturity with shortest duration of 71.72 and 133.17 days, 
respectively. The longest flowering and maturity duration (125.33 and 167.66 days) was observed in the plots of PRIL-B-155. The mean performance was ranged from 71.72 to 125.33 days for 50 per cent flowering and 133.17 to 167.66 days for maturity with mean value of 106.03 and 150.07 days, respectively (Table 1 and 2). These findings are in accordance with the earlier findings of Birhan et al., (2013), Nagy et al., (2013), Singh et al., (2013) and Vanisree et al., (2013).

\section{Yield parameters}

Evaluation of genotypes for pod length varied significantly among the genotypes with wider variation $(4.24$ to $6.13 \mathrm{~cm})$. The maximum pod length was recorded in GRG-2009 (6.13 $\mathrm{cm})$ and the shortest in PRIL-B-165 $(4.24 \mathrm{~cm})$ (Table 2). The variation in pod length among the genotypes was mainly due to the genotypic characters, which is primarily influenced by heredity.

Pod length determines the number of seeds to be accommodated. This indicates the long pod will accommodate more seeds than short pod genotypes. Thus, genotypes with long pod could possess high yielding ability such as GRG-2009.

Pod length plays major role in determining pigeonpea yield since it is closely related to pod weight in single plant. In present study, wide range was observed for pod weight (5.40 to $9.06 \mathrm{~g}$ ) with mean of $6.78 \mathrm{~g}$. significantly highest pod weight recorded in GRG-2009 (9.06 g). Whereas, PRIL-B-165 genotype recorded lowest pod weight $(5.40 \mathrm{~g})$ at harvest (Table 2).

The differential response of pod weight in the genotype could be attributed to its genetic potentiality of the genotypes which is primarily influenced by heredity. Significantly highest value of 100 seed weight was recorded in GRPH-2 (13.83 g) and lowest was observed in AKT-9913 (7.30 g) with considerable variation (7.30 to $13.83 \mathrm{~g})$ (Table 2). It showed high genetic advance over the mean in both the genotypes. These findings are in accordance with earlier reports of Sharma et al., (2012), Nagy et al., (2013), Rao et al., (2013) and Saroj et al., (2013). The revealed genetic variability indicated that the genotypes are genetically diverse and that variations are due to presence of inherent genetic differences among the genotypes.

Yield being a complex character, is the sum of many morphological and biochemical events which occurred during crop growth and development. Many varieties are to be screened to suit varied agro-climatic conditions. In our present investigation, 64 genotypes were screened for seed yield and yield attributing characters.

Results showed considerable amount of variability for seed yield plant ${ }^{-1}$ and seed yield $\mathrm{ha}^{-1}$ as the values ranged from 31.69 to 54.16 $\mathrm{g}$ plant $^{-1}$ and 351.15 to $1687.21 \mathrm{~kg} \mathrm{ha}^{-1}$, respectively. Significantly highest seed yield plant $^{-1}$ was observed in GRG-2009 (54.16 g plant $^{-1}$ and $1687.21 \mathrm{~kg} \mathrm{ha}^{-1}$ ) and it was on par with genotypes like ICP-11320 (52.59 g plant $^{-1}$ and $1599.34 \mathrm{~kg} \mathrm{ha}^{-1}$ ) (Table 2).

However, lowest was noticed in PRIL-B-165 (31.69 g plant ${ }^{-1}$ and $351.15 \mathrm{~kg} \mathrm{ha}{ }^{-1}$, respectively). The high heritability coupled with high genetic advance as a per cent mean was also recorded for this trait and this is supported by the earlier report of Thimmaraju (2012) whereas, low heritability and moderate genetic advance as a per cent mean was observed by Birhan et al., (2013) for this trait. Seed yield is mainly depending on source to sink relation. As the reproductive phase get more photosynthetic assimilate, an increase in seed yield is resulted. 
Table.1 Evaluation of pigeonpea genotypes for growth and reproductive characters

\begin{tabular}{|c|c|c|c|c|c|c|}
\hline Genotypes & $\begin{array}{l}\text { Plant } \\
\text { height } \\
(\mathrm{cm})\end{array}$ & $\begin{array}{l}\text { Number of } \\
\text { branches } \\
\text { per plant }\end{array}$ & $\begin{array}{c}\text { Leaf } \\
\text { area } \\
\left(\mathbf{d m}^{2}\right. \\
\left.\text { plant }^{-1}\right)\end{array}$ & $\begin{array}{l}\text { Chlorophyll } \\
\text { content } \\
\text { (SPAD) value }\end{array}$ & $\begin{array}{c}\text { Dry matter } \\
\text { production }^{(g} \\
\left.\text { plant }^{-1}\right)\end{array}$ & $\begin{array}{c}\text { Days to } 50 \\
\text { per cent } \\
\text { flowering }\end{array}$ \\
\hline NTL-900 & 165.36 & 45.10 & 13.52 & 14.50 & 252.72 & 98.83 \\
\hline GRG-333 & 155.60 & 44.21 & 14.38 & 14.83 & 253.77 & 98.33 \\
\hline $\begin{array}{l}\text { GRG- } \\
\text { 2009-1 }\end{array}$ & 148.18 & 40.84 & 13.24 & 12.67 & 253.71 & 98.83 \\
\hline $\begin{array}{l}\text { GRGB- } \\
131\end{array}$ & 149.39 & 45.60 & 14.51 & 16.00 & 255.23 & 97.83 \\
\hline $\begin{array}{l}\text { GRGC- } \\
132\end{array}$ & 134.62 & 44.97 & 14.41 & 15.50 & 252.41 & 100.83 \\
\hline GRG-8793 & 145.82 & 46.22 & 14.46 & 9.25 & 254.10 & 96.00 \\
\hline $\begin{array}{l}\text { AKTE-11- } \\
1\end{array}$ & 162.19 & 44.32 & 13.81 & 17.25 & 254.51 & 104.00 \\
\hline $\begin{array}{l}\text { RVKT- } \\
261\end{array}$ & 174.45 & 45.08 & 13.45 & 10.50 & 253.44 & 107.67 \\
\hline IPPF-5M5 & 151.20 & 42.97 & 13.38 & 8.50 & 254.49 & 106.33 \\
\hline GRG-82 & 156.33 & 51.44 & 14.63 & 16.42 & 257.62 & 100.00 \\
\hline IPPF-V34 & 154.41 & 46.77 & 14.36 & 15.75 & 256.65 & 96.17 \\
\hline GRG-2009 & 154.50 & 57.01 & 15.80 & 12.50 & 264.04 & 102.83 \\
\hline $\begin{array}{l}\text { GPHR-08- } \\
11\end{array}$ & 183.83 & 42.86 & 14.78 & 11.25 & 255.35 & 106.50 \\
\hline $\begin{array}{l}\text { GRG-13- } \\
11\end{array}$ & 155.01 & 53.16 & 14.29 & 13.00 & 256.31 & 106.67 \\
\hline ICP-11320 & 148.24 & 55.87 & 15.56 & 10.25 & 261.31 & 94.17 \\
\hline AKT-9913 & 156.19 & 46.76 & 14.58 & 8.75 & 251.35 & 106.33 \\
\hline $\begin{array}{l}\text { BDN- } \\
\text { 2008-12 }\end{array}$ & 152.33 & 47.22 & 13.84 & 10.00 & 255.63 & 104.83 \\
\hline RVK-275 & 158.93 & 44.18 & 14.25 & 14.58 & 255.58 & 110.67 \\
\hline $\begin{array}{l}\text { BDN- } \\
\text { 2008-1 }\end{array}$ & 160.63 & 47.20 & 14.65 & 7.75 & 254.77 & 109.00 \\
\hline TDRG-33 & 157.86 & 45.07 & 14.24 & 9.25 & 256.76 & 101.50 \\
\hline PT-04-307 & 157.22 & 43.14 & 14.51 & 6.50 & 256.13 & 108.67 \\
\hline
\end{tabular}




\begin{tabular}{|c|c|c|c|c|c|c|}
\hline GRG-K1 & 166.19 & 46.47 & 14.52 & 8.25 & 256.46 & 103.00 \\
\hline $\begin{array}{l}\text { PRIL-B- } \\
136\end{array}$ & 166.77 & 44.59 & 14.37 & 13.00 & 257.80 & 103.50 \\
\hline $\begin{array}{l}\text { PRIL-B- } \\
155\end{array}$ & 160.04 & 44.27 & 14.02 & 18.33 & 256.47 & 125.33 \\
\hline $\begin{array}{l}\text { PRIL-B- } \\
165\end{array}$ & 166.56 & 39.16 & 13.01 & 18.75 & 249.93 & 124.42 \\
\hline AGL-1666 & 154.34 & 46.81 & 14.60 & 11.08 & 254.40 & 112.83 \\
\hline AGL-1919 & 149.42 & 46.20 & 14.24 & 11.75 & 255.40 & 114.83 \\
\hline AGL-2013 & 153.16 & 45.92 & 14.68 & 16.67 & 256.94 & 110.00 \\
\hline AGL-1643 & 145.26 & 46.11 & 14.38 & 20.67 & 256.67 & 112.42 \\
\hline MARUTI & 140.64 & 46.95 & 14.68 & 10.67 & 256.16 & 108.33 \\
\hline WRP-1 & 149.21 & 44.26 & 14.48 & 13.50 & 256.37 & 103.83 \\
\hline TS-3R & 136.90 & 48.10 & 14.56 & 10.33 & 255.32 & 95.00 \\
\hline $\begin{array}{l}\text { RVKT- } \\
260\end{array}$ & 161.75 & 46.70 & 14.41 & 6.83 & 256.11 & 103.83 \\
\hline $\begin{array}{l}\text { BRG-10- } \\
02\end{array}$ & 154.10 & 45.84 & 13.93 & 8.33 & 255.94 & 116.17 \\
\hline $\begin{array}{l}\text { BRG-11- } \\
01\end{array}$ & 156.04 & 48.24 & 14.28 & 6.17 & 257.01 & 122.50 \\
\hline PT-257 & 163.07 & 45.77 & 14.61 & 16.25 & 255.81 & 109.83 \\
\hline $\begin{array}{l}\text { SKNP- } \\
1005\end{array}$ & 156.35 & 47.28 & 14.64 & 14.50 & 255.36 & 106.17 \\
\hline WRGE-97 & 170.26 & 46.06 & 14.33 & 10.75 & 256.50 & 107.50 \\
\hline GRG-140 & 154.90 & 46.22 & 14.00 & 15.00 & 255.59 & 100.17 \\
\hline ICP-8793 & 147.32 & 45.69 & 14.52 & 18.50 & 256.45 & 92.17 \\
\hline ICP-11320 & 150.18 & 47.05 & 14.59 & 17.00 & 254.66 & 92.33 \\
\hline $\begin{array}{l}\text { CORG- } \\
9701\end{array}$ & 156.36 & 47.34 & 13.73 & 11.25 & 257.11 & 98.50 \\
\hline ICP-16317 & 144.29 & 45.74 & 13.93 & 6.00 & 256.80 & 108.00 \\
\hline ICP-14944 & 148.21 & 47.12 & 13.96 & 8.50 & 255.33 & 71.72 \\
\hline ICP-14840 & 164.56 & 46.87 & 14.40 & 11.25 & 255.28 & 104.50 \\
\hline ICP-14471 & 152.87 & 48.18 & 13.89 & 13.25 & 256.40 & 103.83 \\
\hline
\end{tabular}




\begin{tabular}{|c|c|c|c|c|c|c|}
\hline AGL-1603 & 158.52 & 47.19 & 14.30 & 16.25 & 255.65 & 106.50 \\
\hline AGL-2249 & 149.29 & 46.52 & 14.61 & 12.75 & 256.59 & 118.00 \\
\hline AGL-1632 & 147.40 & 46.16 & 14.46 & 17.00 & 256.43 & 117.67 \\
\hline GRG-160 & 157.06 & 47.68 & 14.66 & 10.75 & 254.46 & 115.33 \\
\hline $\begin{array}{l}\text { RVK-275- } \\
\text { R-I }\end{array}$ & 149.16 & 47.86 & 14.26 & 14.25 & 256.12 & 112.50 \\
\hline $\begin{array}{l}\text { ICPL } \\
14001\end{array}$ & 128.13 & 46.36 & 14.42 & 24.00 & 255.09 & 104.50 \\
\hline $\begin{array}{l}\text { ICPL } \\
\text { 99050 }\end{array}$ & 151.86 & 46.45 & 14.33 & 15.00 & 256.21 & 111.67 \\
\hline $\begin{array}{l}\text { ICPL } \\
20116\end{array}$ & 146.13 & 47.64 & 14.41 & 16.75 & 254.57 & 109.50 \\
\hline $\begin{array}{l}\text { ICPL } \\
20136\end{array}$ & 145.90 & 48.56 & 14.24 & 8.00 & 255.73 & 111.83 \\
\hline $\begin{array}{l}\text { ICPL } \\
96053\end{array}$ & 144.98 & 47.65 & 14.50 & 23.00 & 256.35 & 113.00 \\
\hline $\begin{array}{l}\text { ICPL } \\
96061\end{array}$ & 149.80 & 48.20 & 14.59 & 10.75 & 255.53 & 114.00 \\
\hline $\begin{array}{l}\text { ICPL } \\
99044\end{array}$ & 145.88 & 47.29 & 14.66 & 10.25 & 256.32 & 113.83 \\
\hline $\begin{array}{l}\text { ICPL } \\
85051\end{array}$ & 145.77 & 47.62 & 14.81 & 10.50 & 256.50 & 113.17 \\
\hline GRPH-1 & 151.00 & 47.23 & 13.99 & 14.75 & 255.44 & 102.33 \\
\hline GRPH-2 & 154.62 & 47.19 & 14.06 & 22.00 & 256.33 & 108.33 \\
\hline MARUTI & 140.64 & 46.95 & 14.68 & 10.67 & 256.16 & 108.33 \\
\hline WRP-1 & 149.21 & 44.26 & 14.48 & 13.50 & 256.37 & 103.83 \\
\hline TS-3R & 136.90 & 48.10 & 14.56 & 10.33 & 255.32 & 95.00 \\
\hline Mean & 153.17 & 46.59 & 14.33 & 13.00 & 255.71 & 106.03 \\
\hline Minimum & 128.13 & 39.16 & 13.01 & 6.00 & 249.93 & 71.72 \\
\hline Maximum & 183.83 & 57.01 & 15.80 & 24.00 & 264.04 & 125.33 \\
\hline S.Em \pm & 2.38 & 0.77 & 0.28 & 0.83 & 1.26 & 0.93 \\
\hline CD @ 5\% & 6.66 & 2.17 & 0.80 & 2.34 & 3.53 & 2.62 \\
\hline
\end{tabular}


Table.2 Evaluation of pigeonpea genotypes for yield characters

\begin{tabular}{|c|c|c|c|c|c|c|}
\hline Genotypes & $\begin{array}{l}\text { Days to } \\
\text { maturity }\end{array}$ & $\begin{array}{c}\text { Pod } \\
\text { weight } \\
\text { (g) }\end{array}$ & $\begin{array}{l}\text { Pod } \\
\text { length } \\
(\mathrm{cm})\end{array}$ & $\begin{array}{c}\text { Test } \\
\text { weight } \\
\text { (g) }\end{array}$ & $\begin{array}{l}\text { Seed yield (g } \\
\left.\text { plant }^{-1}\right)\end{array}$ & $\begin{array}{c}\text { Seed yield } \\
\left(\mathrm{kg} \mathrm{ha}^{-1}\right)\end{array}$ \\
\hline NTL-900 & 145.33 & 6.49 & 4.74 & 10.30 & 36.55 & 367.95 \\
\hline GRG-333 & 141.33 & 7.39 & 4.65 & 9.63 & 33.27 & 520.05 \\
\hline GRG-2009-1 & 143.67 & 6.79 & 4.99 & 13.23 & 32.40 & 579.86 \\
\hline GRGB-131 & 145.50 & 6.49 & 4.71 & 10.58 & 38.06 & 1284.62 \\
\hline GRGC-132 & 144.67 & 7.78 & 4.83 & 7.52 & 37.63 & 642.69 \\
\hline GRG-8793 & 140.00 & 6.81 & 4.88 & 11.05 & 38.13 & 1174.64 \\
\hline AKTE-11-1 & 150.33 & 6.87 & 4.63 & 10.93 & 39.68 & 906.04 \\
\hline RVKT-261 & 154.17 & 7.82 & 4.71 & 11.60 & 38.92 & 1004.52 \\
\hline IPPF-5M5 & 155.00 & 6.75 & 4.62 & 10.58 & 45.30 & 1041.75 \\
\hline GRG-82 & 143.00 & 7.76 & 5.13 & 8.13 & 51.12 & 854.99 \\
\hline IPPF-V34 & 142.67 & 7.59 & 4.98 & 11.57 & 40.73 & 928.17 \\
\hline GRG-2009 & 150.00 & 9.06 & 6.13 & 13.18 & 54.16 & 1687.21 \\
\hline GPHR-08-11 & 148.50 & 6.65 & 4.63 & 8.63 & 41.15 & 726.91 \\
\hline GRG-13-11 & 154.83 & 7.49 & 5.38 & 8.00 & 52.58 & 1484.83 \\
\hline ICP-11320 & 135.83 & 8.74 & 5.65 & 9.33 & 52.59 & 1599.34 \\
\hline AKT-9913 & 150.50 & 7.43 & 4.80 & 7.30 & 41.94 & 1257.35 \\
\hline BDN-2008-12 & 145.50 & 6.55 & 4.93 & 8.38 & 41.94 & 766.81 \\
\hline RVK-275 & 152.33 & 6.37 & 4.64 & 9.00 & 40.43 & 1081.24 \\
\hline BDN-2008-1 & 153.83 & 7.35 & 4.80 & 10.98 & 40.74 & 1002.45 \\
\hline TDRG-33 & 142.67 & 6.24 & 4.75 & 9.21 & 44.94 & 1059.72 \\
\hline PT-04-307 & 152.00 & 7.10 & 4.67 & 11.20 & 42.67 & 942.82 \\
\hline GRG-K1 & 143.33 & 6.03 & 4.75 & 9.48 & 44.38 & 837.48 \\
\hline PRIL-B-136 & 143.50 & 6.74 & 4.92 & 10.68 & 41.88 & 1002.69 \\
\hline PRIL-B-155 & 167.66 & 7.64 & 5.08 & 12.85 & 42.20 & 1003.22 \\
\hline PRIL-B-165 & 166.54 & 5.40 & 4.24 & 11.46 & 31.69 & 351.15 \\
\hline AGL-1666 & 153.00 & 5.95 & 4.66 & 10.65 & 41.31 & 664.27 \\
\hline AGL-1919 & 154.17 & 6.55 & 4.42 & 11.25 & 43.38 & 977.74 \\
\hline AGL-2013 & 153.83 & 6.84 & 4.56 & 10.66 & 38.88 & 659.56 \\
\hline AGL-1643 & 157.33 & 5.97 & 4.76 & 10.09 & 44.68 & 565.09 \\
\hline MARUTI & 153.00 & 6.07 & 4.95 & 8.53 & 45.22 & 831.01 \\
\hline WRP-1 & 144.83 & 6.22 & 4.76 & 7.85 & 45.22 & 1211.21 \\
\hline TS-3R & 135.50 & 6.90 & 4.76 & 10.04 & 48.05 & 1317.09 \\
\hline RVKT-260 & 162.00 & 6.21 & 4.72 & 8.65 & 42.10 & 642.39 \\
\hline BRG-10-02 & 157.50 & 6.41 & 4.64 & 10.52 & 45.49 & 1155.65 \\
\hline BRG-11-01 & 164.67 & 6.91 & 4.66 & 10.89 & 39.68 & 1192.35 \\
\hline PT-257 & 153.83 & 6.24 & 4.58 & 10.50 & 46.29 & 1034.39 \\
\hline SKNP-1005 & 152.33 & 6.20 & 4.87 & 9.80 & 41.49 & 1138.69 \\
\hline WRGE-97 & 150.67 & 6.44 & 5.01 & 8.73 & 42.83 & 1211.62 \\
\hline
\end{tabular}




\begin{tabular}{|c|c|c|c|c|c|c|}
\hline GRG-140 & 144.17 & 5.41 & 4.91 & 9.66 & 39.58 & 1234.01 \\
\hline ICP-8793 & 137.50 & 7.39 & 5.25 & 11.53 & 46.10 & 1250.26 \\
\hline ICP-11320 & 135.67 & 6.61 & 5.05 & 10.08 & 43.65 & 1163.07 \\
\hline CORG-9701 & 141.17 & 5.83 & 4.95 & 7.85 & 43.25 & 1088.96 \\
\hline ICP-16317 & 141.83 & 7.25 & 5.21 & 9.75 & 45.80 & 706.26 \\
\hline ICP-14944 & 133.17 & 6.11 & 5.22 & 8.03 & 38.22 & 1368.28 \\
\hline ICP-14840 & 144.33 & 6.16 & 5.28 & 8.20 & 39.75 & 849.10 \\
\hline ICP-14471 & 147.67 & 7.04 & 5.13 & 10.84 & 41.51 & 1253.19 \\
\hline AGL-1603 & 157.33 & 6.99 & 4.97 & 10.73 & 40.35 & 957.78 \\
\hline AGL-2249 & 156.83 & 5.83 & 4.85 & 10.88 & 38.96 & 769.34 \\
\hline AGL-1632 & 145.83 & 6.94 & 4.98 & 10.30 & 39.12 & 940.71 \\
\hline GRG-160 & 144.33 & 5.76 & 4.88 & 10.20 & 41.54 & 779.58 \\
\hline RVK-275-R-I & 153.17 & 6.09 & 4.83 & 9.35 & 39.04 & 882.73 \\
\hline ICPL 14001 & 155.83 & 6.73 & 4.65 & 10.10 & 34.83 & 1283.14 \\
\hline ICPL 99050 & 164.00 & 6.44 & 4.65 & 10.99 & 39.98 & 778.93 \\
\hline ICPL 20116 & 163.33 & 5.85 & 4.80 & 10.05 & 36.23 & 1069.34 \\
\hline ICPL 20136 & 162.00 & 7.11 & 5.10 & 12.55 & 40.12 & 1057.34 \\
\hline ICPL 96053 & 162.17 & 7.61 & 5.03 & 11.53 & 36.60 & 1002.06 \\
\hline ICPL 96061 & 160.33 & 7.09 & 5.00 & 11.18 & 38.28 & 694.10 \\
\hline ICPL 99044 & 162.83 & 7.10 & 5.52 & 11.60 & 38.95 & 720.93 \\
\hline ICPL 85051 & 158.00 & 7.68 & 5.50 & 11.60 & 38.69 & 715.16 \\
\hline GRPH-1 & 146.83 & 7.98 & 5.28 & 12.95 & 39.06 & 1371.58 \\
\hline GRPH-2 & 148.17 & 7.73 & 5.24 & 13.83 & 39.53 & 839.73 \\
\hline MARUTI & 153.00 & 6.07 & 4.95 & 8.53 & 45.22 & 831.01 \\
\hline WRP-1 & 144.83 & 6.22 & 4.76 & 7.85 & 45.22 & 1211.21 \\
\hline TS-3R & 135.50 & 6.90 & 4.76 & 10.04 & 48.05 & 1317.09 \\
\hline Mean & 150.07 & 6.78 & 4.92 & 10.20 & 41.67 & 981.94 \\
\hline Minimum & 133.17 & 5.40 & 4.24 & 7.30 & 31.69 & 351.15 \\
\hline Maximum & 167.66 & 9.06 & 6.13 & 13.83 & 54.16 & 1687.21 \\
\hline S.Em \pm & 1.53 & 0.32 & 0.21 & 0.11 & 1.28 & 46.20 \\
\hline CD@ $9 \%$ & 4.28 & 0.91 & 0.61 & 0.31 & 3.58 & 129.30 \\
\hline
\end{tabular}

Improvement in seed yield components of above said genotypes might be due to improved vegetative growth i.e. higher leaf area, more number of branches and chlorophyll content. Due to higher leaf area there might have been increased photosynthetic activity with the help of higher chlorophyll content and wherein, the uptake of carbon dioxide might be more leading to higher production of carbohydrates and thereby translocation of photosynthates to sink leading to higher seed yield (Wiangsamut et al., 2006 and Feng et al., 2007). Among the 64 genotypes GRG-2009 registered significantly highest leaf area (15.80 dm $\mathrm{dm}^{2}$ plant $^{-1}$ ), number of branches plant $^{-1}$ (57.01), chlorophyll content (66.82 SPAD), pod weight (9.06 g), pod length (6.13 $\mathrm{cm})$, seed yield (54.16 g plant ${ }^{-1}$ and 1687.21 $\left.\mathrm{kg} \mathrm{ha}{ }^{-1}\right)$. Whereas, ICP-14944 (71.72 days) 
and ICP-14944 (133.17 days) took less number of days to 50 per cent lowering and days to maturity compared to other genotypes. Among 64 genotypes GRG-2009 and ICP11320 are best performers for plant growth and yield attributing characters. These can be utilized for pigeonpea crop improvement programmes.

\section{References}

Anonymous, 2014, http://agricoop.nic. in/agristatistics.

Ashrafuzzaman, M., Islam, R., Ismai, R., Shahidullah, S. M. and Hanafi, M. M., 2009, Evaluation of six aromatic rice varieties for yield and yield contributing characters. Int. J. Agric. Biol., 11: 616620.

Begum, M., Hossain, M. A., Hossain, F. M. and Hasan, A. K., 2015, Genetic variability for grain yield and yield associated traits in transplant aman rice (Oryza sativa L.). Res. Agric. Livest. Fish., 2(2): 207-213.

Birhan, T., Zeleke, H., Ayana, A., Tilahun, A. and Chemeda, A., 2013, Genetic variability, heritability and genetic advance in early maturing pigeonpea [Cajanus cajan (L.) Millsp.] genotypes. World J. Agri. Sci., 1(7): 241-247.

De, D. N., 1974, Pigeonpea in evolutionary studies in world crops: diversity and change in the Indian subcontinent. Hutchinson J, ed., London: Cambridge press. Pp. 79-87.

Effisue, A. A., Tongoona, Deera, J. and Ubli, B. E., 2009. Screening of early generation's progenies of interspecific rice genotypes for drought tolerance during vegetative phase. J. Crop Improv., 23: 174-193.

Enujeke, E. C., 2013, Effects of variety and spacing on growth characters of hybrid maize. Asian J. Agri. \& Rural Dev., 3(5): 296-310.
Feng, W., Min, C. F. and Ping, Z. G., 2007, Difference in grain yield and quality among tillers in rice genotypes differing in tillering capacity. Rice Science, 14(2): 135-140.

Grafius, J. E., 1956, Components of yield and a geometrical interpretation in oats. Agron. J., 48: 419-423.

Hoghjensen, H., Myaka, F. A., Sakala, W. D., Kamalongo, D., Ngwira, A., Vesterager, J. M., Odgaard, R. and Adu-gyamfi, J. J., 2007, Yields and qualities of pigeonpea varieties grown under smallholder farmer's conditions in eastern and southern Africa. Afric. J. Agric. Research. 2: 269-278.

Hussain, F., Malik, A. U., Haji, M. A. and Malghani, A. L., 2011, Growth and yield response of two cultivars of mungbean (Vigna radiata L.) to different potassium levels. J. Anim. \& Pla. Sci., 21(3): 622-625.

Jagathjyothi, M., Muthukrishnan, P. and Mohamed Amanullah, M., 2012, Influence of foliar nutrition on growth and yield of transplanted rice. Madras Agric. J., 99(4-6): 275-278.

Munshi, R.U., 2005, A comparative morphophysiological study between two local and two modern rice cultivars. M.sc. Thesis, Bangladesh Agric. Univ., Mymensingh (Bangladesh).

Nagy, K., Sharma, R. N., Nandah, C. and Kanwer, S. S., 2013, Genetic variability and association studies among yield attributes in pigeonpea [Cajanus cajan (L.) Millsp.] accessions of bastar. The Ecoscan., 4: 267-271.

Rao, P. J. M., Upender, M. and Vijay, B. A., 2013, Variability and genetic diversity studies in redgram [Cajanus cajan (L.) Millsp.]. Int. J. App. Bio. Phar. Tech., 4(4): 48-51.

Saxena, K. B., 2008, Genetic improvement of pigeonpea. Trop. Plant. Biol., 1: 159178. 
Sharma, R., Gangwar, K, R. and Yadav, V., 2012, A Study on Genetic variability and correlation in pigeonpea [Cajanus cajan (L.) Millsp.]. Int. J. Sci. and Res., 4(2): 358-361.

Singh, R., Heusden, A. W., Kumar, R., Visser, R. G. F. and Yadav, R. C., 2013, Genetic Diversity of Mungbean (Vigna radiata $\mathrm{L}$.) in iron and zinc content as impacted by Farmers Varietal Selection in Northern India. Eco. Food \& Nutri., 52(2): 148-162.

Sohrabi, Y., Habibi, A., Mohammadi, K., Sohrabi, M., Heidari, G., Khalesro, S. and Khalvandi, M., 2012, Effect of nitrogen $(\mathrm{N})$ fertilizer and foliar-applied iron $(\mathrm{Fe})$ fertilizer at various stages on yield, yield component and chemical composition of soybean (Glycine max L. Merr.) seed. African Journal of Biotechnology, 11(40): 9599-9605.

Thimmaraju. 2012, Evaluation of pigeonpea [Cajanus cajan (L.) Millsp.] minicore collection set for yield and yield related traits. M. Sc. Thesis, Uni. Agric. Sci. Dharwad (India).

Van Der and Maesen, L. J. G., 1980, India is the native home of the pigeonpea. Agril. Univ., Miscellaneous Paper, 19: 257262.

Vange, T. and Egbe, M. O., 2009, Studies on genetic characteristics of pigeonpea germplasm at Otobi, Benue Stata of Nigeria. World J. Agril. Sci., 5(6): 714716.
Vanisree, S., Sreedhar, M. and Raju, S., 2013, Studies on genetic characteristics of pigeonpea and determination of selection criteria with path co-efficient analysis. Int. J. App. Bio. Phar. Tech., 4(2): 223-226.

Varsshney, R. K., Wenbin, C., Yupeng, L., Arvind, K. B., Rachit, K. S., Jessica, A. S., Mark, T. A., Sarwar, A., Guangyi, F., Adam, M. W., Andrew, D. F., Jaime, S., Aiko, I., Reetu, T., Varma, P., Wei, W., Hari, D. U., Shiaw- Pyng, Y., Trushar, S., Sexena, K. B., Todd, M., Richard, McCombie, Bicheng, Y., Gengyun, Z., Huanming, Y., Jun, W., Charles, S., Douglas, R. C., Gregory, D. M., Xun, X. and Scott, A. J., 2012, Draft genome sequence of pigeonpea (Cajanus cajan), an orphan legume crop of resource-poor farmers. Nat. Biotechnol., 30: 83-89.

Vivekanandan, A. S., Gunasena, H. P. M. and Sivananyagam, T., 1972, Statistical Evaluation of accuracy of three techniques used in estimation of leaf area of crop plants. Indian J. Agric. Sci., 42: 857- 860 .

WHO, 2002, World Health Report. www.ctds.info/zinc1.html.

Wiangsamut, B., Teodoro, C., Mendoza and Tanguy, A. L., 2006, Growth dynamics and yield of rice genotypes grown in transplanted and direct-seeded fields. $J$. Agric Tech., 2(2): 299-316.

\section{How to cite this article:}

Hanumanthappa, D., S. N. Vasudevan, N. M. Shakuntala, N. M. Muniswamy, Sangeetha I. Maacha and Umesh Hiremath. 2020. Evaluation of Pigeonpea Genotypes for Growth and Yield Characters. Int.J.Curr.Microbiol.App.Sci. 9(04): 2625-2637.

doi: https://doi.org/10.20546/ijcmas.2020.904.314 